\title{
Desafios extremos da internet e contágio psíquico: sintomas da cultura do espetáculo
}

\author{
Extreme challenges of the internet and psychic contagion: symptoms of \\ spectacle culture
}

\section{Juegos extremos de internet y contagio psíquico: síntomas de la cultura del espectáculo}

\author{
Malena Segura Contrera ${ }^{1, a}$ \\ malenacontrera@uol.com | http://orcid.org/oooo-0003-4334-9467 \\ Leonardo de Souza Aloi Torres ${ }^{1, b}$ \\ leosouzatorres@gmail.com | https://orcid.org/oooo-0002-0511-8775 \\ ${ }^{1}$ Universidade Paulista, Programa de Pós-graduação em Comunicação. São Paulo, SP, Brasil. \\ a Doutorado em Comunicação e Semiótica pela Pontifícia Universidade Católica de São Paulo. \\ b Doutorado em Comunicação e Cultura Mediática pela Universidade Paulista.
}

\section{RESUMO}

O presente artigo analisa os padrões de manifestação dos 'desafios da internet', manifestação viral da qual participam principalmente pré-adolescentes e adolescentes, e que estimulam teleparticipação mundial em desafios geradores de estados alterados de consciência que carregam um risco de morte em potencial. Objetivou-se traçar os padrões de incidência da ferramenta Google Trends para mapear padrões de manifestação que são analisados do ponto de vista dos contágios psíquicos das massas próprios das sociedades tomadas pelas redes de comunicação. À análise dos padrões de incidência segue-se uma reflexão teórica sobre o fenômeno e os seus desdobramentos a partir das teorias da comunicação, da mídia e da psicologia junguiana, especialmente acerca dos fenômenos das massas. Para a discussão, utilizaram-se como referências básicas Dietmar Kamper, Jean Baudrillard, Norval Baitello Junior e Malena Segura Contrera.

Palavras-chave: Desafios de internet; Contágio psíquico; Comunicação viral; Estados alterados de consciência; Transparência.

\section{ABTRACT}

This article analyses the patterns of manifestation of 'internet challenges', a viral manifestation in which mainly preadolescents and adolescents participate and which stimulates worldwide participation in challenges that generate altered states of consciousness that carry a potential risk of death. The objective was to trace the patterns of incidence of the Google Trends tool to map patterns of manifestation that 
are analyzed from the point of view of the psychic contagions of the masses of the societies taken by the communication networks. The analysis of the patterns of incidence is followed by a theoretical reflection on the phenomenon and its consequences based on the theories of communication, the media and Jungian psychology, especially concerning the phenomena of the masses. For the discussion, we used Dietmar Kamper, Jean Baudrillard, Norval Baitello Junior and Malena Segura Contrera as basic references.

Keywords: Internet challenges; Psychic contagion; Viral communication; Altered states of consciousness; Transparency.

\section{RESUMEN}

Este artículo analisar los patrones de manifestación de los 'desafíos de internet', manifestación viral en la que participan principalmente preadolescentes y adolescentes y que promueven la participación mundial en desafíos que generan estados alterados de conciencia que conllevan un potencial riesgo de muerte. El objetivo fue rastrear los patrones de incidencia de la herramienta Google Trends para mapear patrones de manifestación que se analizan desde el punto de vista de los contagios psíquicos de las masas de las sociedades tomadas por las redes de comunicación. Al análisis de los patrones de incidencia le sigue una reflexión teórica sobre el fenómeno y sus consecuencias a partir de las teorías de la comunicación, los medios de comunicación y la psicología junguiana, especialmente en lo que respecta a los fenómenos de masas. Para la discusión se utilizaron como referencias básicas Dietmar Kamper, Jean Baudrillard, Norval Baitello Junior y Malena Segura Contrera.

Palabras clave: Desafíos de internet; Contagio psiquico; Comunicación viral; Estados alterados de conciencia; Transparencia.

Contribuição dos autores:

Concepção e desenho do estudo: Malena S. Contrera.

Aquisição, análise ou interpretação dos dados: Leonardo de Souza Aloi Torres.

Redação do manuscrito: Malena S. Contrera e Leonardo de Souza Aloi Torres.

Revisão crítica do conteúdo intelectual: Malena S. Contrera.

Declaração de conflito de interesses: não há.

Fontes de financiamento: Conselho Nacional de Desenvolvimento Científico e Tecnológico (CNPq).

Considerações éticas: não há.

Agradecimentos/Contribuições adicionais: não há.

Histórico do artigo: submetido: 8 set. 2020 | aceito: 1 fev. 2021 | publicado: 30 jun. 2021.

Apresentação anterior: não houve.

Licença CC BY-NC atribuição não comercial. Com essa licença é permitido acessar, baixar (download), copiar, imprimir, compartilhar, reutilizar e distribuir os artigos, desde que para uso não comercial e com a citação da fonte, conferindo os devidos créditos de autoria e menção à Reciis. Nesses casos, nenhuma permissão é necessária por parte dos autores ou dos editores. 


\title{
INTRODUÇÃO
}

A relação entre os ambientes sociais e os sintomas psicológicos que vemos eclodirem de forma mais ou menos epidêmica não passa despercebida pelas áreas de Psicologia ou Sociologia. No entanto, muito pouco se tem pesquisado sobre como os ambientes sociais fortemente marcados pela onipresença dos meios eletrônicos de comunicação apresentam sintomas específicos dessa condição.

A internet possibilitou e ainda possibilita uma ambiência de interação social e virtual na qual seus usuários trocam mensagens, imagens, vídeos, memes etc. Contudo, em meio a todas as possibilidades que se abrem nas redes sociais digitais, recentemente, surgiu um fenômeno conhecido como 'desafios', que, entre peculiares e inofensivos, podem ser bastante prejudiciais à saúde e colocar a vida dos participantes em risco. O potencial de perigo à saúde para os que praticam esses jogos extremos chama-nos a atenção por entendermos que há nesses casos algo que põe em diálogo justamente essas imbricações e mútuas interferências entre saúde mental e sociedade, especificamente a sociedade mediática.

O problema proposto no presente artigo trata do caráter epidêmico das mídias digitais. Se por um lado o viral pode ser estudado pela Ciência da Informação, por outro cabe à Ciência da Comunicação estudar o contágio necessário para que o viral ocorra. Gabriel Tarde (2001), Gustave LeBon (1982), Sigmund Freud (2017) e Carl Gustav Jung (2013) já discutiram amplamente sobre o fenômeno do contágio de sentimentos e emoções em grupos sociais. Este trabalho foca no estudo do contágio por meio da teleparticipação mediática. Portanto, pergunta-se: de que maneira os 'desafios da internet' podem contagiar usuários por meio da mídia eletrônica? Afinal, tais desafios não possuem, a priori, intenções mercadológicas, mas um forte apelo ao desejo de êxtase e à espetacularização, que, por sua vez, estão ligados a sentimentos e emoções humanas contagiantes. E praticar o desafio torna-se algo muito instigante, algo que exerce verdadeiro fascínio, a ponto de se colocar a própria vida em risco. Para tanto, foram escolhidas como metodologias a coleta de dados e a revisão bibliográfica, auxiliadas pela ferramenta Google Trends, a fim de analisar os índices de acesso que evidenciam os picos indicativos do caráter de contágio dos desafios.

Dessa forma, o instrumento Google Trends computa a relevância e a recorrência relativa de termos pesquisados no Google pelo usuário comum da internet, possibilitando o conhecimento de tendências e assuntos na web.

\begin{abstract}
Os resultados da pesquisa são proporcionais ao tempo e à localização de uma consulta através do seguinte processo: cada ponto de dados é dividido pelo total de pesquisas da geografia e do intervalo de tempo que representa para comparar a popularidade relativa. Caso contrário, os locais com o maior volume de pesquisa apresentariam sempre a classificação mais elevada; os números resultantes são, em seguida, dimensionados num intervalo de o a 100 com base na proporção de um tópico em relação a todas as pesquisas em todos os tópicos; regiões diferentes que mostram o mesmo interesse de pesquisa num termo nem sempre têm os mesmos volumes totais de pesquisa (GOOGLE TRENDS, 2020).
\end{abstract}

A ferramenta usa uma amostra imparcial de dados do Google a fim de não comprometer qualquer informação pessoal, mas também corroborando para entender o usuário mediano.

Apenas uma percentagem das pesquisas é utilizada para compilar dados do Trends. Existem dois tipos de dados do Trends: os dados em tempo real são uma amostra aleatória de pesquisas dos últimos sete dias. Já os dados em tempo não real são uma amostra aleatória de dados de pesquisa do Google que podem remontar a um período desde 2004 até 36 horas antes da pesquisa. Depois de recolhermos os dados de pesquisa, categorizamo-los, associamo-los a um tópico e removemos todas as informações pessoais (GOOGLE TRENDS, 2020).

Enfim, os dados compilados são elencados pelo próprio instrumento em prol de uma otimização:

[...] pesquisas efetuadas por poucas pessoas: o Trends mostra apenas dados de termos populares, pelo que os termos de pesquisa com um volume baixo são apresentados como 'o'. Pesquisas duplicadas: o Trends elimina pesquisas repetidas da mesma pessoa durante 
um curto período de tempo. Caracteres especiais: o Trends filtra consultas com apóstrofos ou outros caracteres especiais (GOOGLE TRENDS, 2020).

Em síntese, o instrumento Google Trends pode auxiliar na identificação de tendências e assuntos que crescem vertiginosamente em âmbito mundial. Tratando-se de dados que ganham relevância de maneira exponencial, pode-se considerar que a ferramenta também revela contágios ou viralizações.

Estudiosos de epidemiologia desenvolveram um trabalho elucidando que uma análise das pesquisas do Google poderia prever epidemias de doenças, visto que existe uma tendência dos usuários, quando preocupados com sua saúde, a pesquisarem primeiramente seus sintomas no Google antes de se encaminharem para um profissional da saúde. Por exemplo, os termos 'tosse' e 'gripe' são mais pesquisados no inverno, isto é, em épocas mais propensas a epidemias [...]. Entretanto, os autores afirmam que a ferramenta Google Trends carece de precisão, pois, na última década, comparando os números entre o $\mathrm{G}$. Trends e os dados do Centro de Controle [de Prevenção] de Doenças (CDC) de respectivos países, o Trends revelou uma previsão epidemiológica duas vezes maior do que os registros dos CDCs (CONTRERA; TORRES, 2019, p. 02).

Apesar dessas considerações, também é preciso conhecer o ponto de vista a partir do qual os autores estão discutindo. São necessários dados precisos que correspondam aos dos CDCs. Mas essa, digamos, dissonância pode ser reveladora para as áreas da Comunicação e da Psicologia:

[...] o Google Trends não revela a ocorrência das doenças ou dos sintomas dos usuários, mas o estado psíquico coletivo gerado por elas, como o medo, o pânico, a preocupação, a curiosidade etc. Nesse contexto, a relação Google/usuário é comparável à relação entre médico/enfermo, ou ainda à relação tradicional entre Oráculo e consulente, como investigado por Miklos (2012) que diagnostica a existência de uma percepção social de que o Google seja onisciente. Estamos tratando de situações em que há uma angústia humana que faz indivíduos buscarem respostas, previsões etc. Os próprios Seifter et al. (2010) e Lazer et al. (2013) foram envolvidos pelo sentido oracular da ferramenta quando afirmam que é possível, por meio do Google, prever as enfermidades na população mundial. Portanto, apesar de os resultados do Google Trends não serem tão satisfatórios para a epidemiologia, eles interessam aos estudos do imaginário e também à Psicologia (CONTRERA; TORRES, 2019, p. 03).

Há uma lista de alguns desses desafios muito recorrentes nas redes sociais digitais, tais como o 'desafio Planking', que consiste em um indivíduo tirar uma foto posicionado em um local perigoso, de bruços, deixando parte de seu corpo suspensa no ar. Ao realizar esse desafio um jovem australiano morreu, pois o fez do sétimo andar de um edifício. Outro é o 'desafio do preservativo': o objetivo é aspirar o objeto pelo nariz e inspirar até que o preservativo seja sugado para ser, depois, retirado pela boca. Vieira (2016) elenca riscos como sinusite grave, obstrução pulmonar e, consequentemente, morte. Existe também o 'desafio das 72 horas', no qual o indivíduo deve desaparecer durante os três dias, sem avisar a ninguém nem dar qualquer sinal de vida. Por fim, existe o 'desafio Kiki', que consiste em um motorista, no trânsito, sair do carro em movimento, ao som de qualquer música, dançar fora do carro e voltar para o carro logo em seguida. Há muitos outros desafios e outros mais ainda estão por vir, já que essa prática cresce com o uso das redes (VIEIRA, 2016).

O que chama a atenção em todos esses desafios é o caráter viral. A contemporaneidade, no que tange às relações mediadas por aparatos eletrônicos, tem utilizado em demasia os termos 'vírus' e 'viral' para designar fenômenos que ocorrem por meio de aparatos eletrônicos em rede. Os termos 'vírus' e 'viral', apropriados da Biologia, possuem conceitos diversos em sua origem.

$\mathrm{O}$ vírus de computador consiste num pequeno programa que pode infectar outros programas, modificando-os de maneira a permitir a sua inclusão. A partir de sua instalação, o vírus começa um ciclo de propagação e ataque, causando desde pequenos transtornos até danos irreparáveis. Com o intuito de evitar a ação prejudicial do vírus, torna-se necessária a análise de sua estrutura de infecção, propagação e ataque (LIMA; SAFFI; FRANÇA; WEBER, 1996). 
O primeiro vírus de computador foi desenvolvido no ano de 1971 pelo programador Bob Thomas. A partir de então, outros programadores utilizaram o mesmo princípio para praticar crimes e causar transtornos na rede digital.

Existe um padrão de disseminação e infecção dos vírus nos computadores que funcionam em rede, mas um desses vírus nos chamou atenção - o vírus Blaster Worm, também conhecido como Lovesan:

\begin{abstract}
[...] surgiu em 2003 e utilizava os computadores infectados como zumbis para organizar um gigantesco ataque de negação de serviço (DDoS) contra o site de atualização do Windows. Além disso, as máquinas também apresentavam instabilidade no sistema e fechavam o SO sem nenhum motivo aparente. Além de causar um grande estrago em PCs domésticos, o vírus atrapalhou o funcionamento do maior sistema ferroviário dos EUA, prejudicou a intranet da marinha estadunidense e afetou até mesmo alguns escritórios da montadora automobilística BMW. De acordo com a Symantec, pelo menos 188 mil máquinas já haviam sido infectadas pelo Blaster dois dias após seu descobrimento (SOUZA, 2014).
\end{abstract}

Já o termo 'viral' não possui o mesmo conceito de 'vírus', no que tange às relações mediadas por aparatos eletrônicos, porém possui um modus operandi semelhante: o contágio. Enquanto o vírus de computador é indesejado pelos usuários, o conteúdo viral é desejado, principalmente pelo marketing, pois o viral é um contágio baseado em emoções, sentimentos e interesses, por meio da comunicação eletrônica, diferentemente do vírus, que tem um contágio somente informacional (RÜDIGER, 2013).

Existe uma vasta discussão sobre o fenômeno da internet e o da viralização nas ciências, como a da Informação, a da Comunicação e a Sociologia (RIBEIRO; ARAÚJO; NOGUEIRA; KELLER, 2019). Entrevistas realizadas com profissionais de publicidade, propaganda e marketing esclarecem o termo 'viral' em suas concepções (SILVA, 2008): para esses profissionais, o viral é uma disseminação vantajosa e quase que instantânea de um conteúdo digital (notícias, imagens, memes etc.), tem um custo-benefício desejável para realizar propaganda e publicidade, porém, segundo os entrevistados, o conteúdo, ao viralizar, torna-se incontrolável e epidêmico, podendo gerar reações imprevisíveis no público contagiado.

Há muito tempo sabe-se do alerta da sociedade do espetáculo (DEBORD, 2003). Guy Debord vai além da presença da comunicação eletrônica de massa no cotidiano do indivíduo, que seria somente seu aspecto mais protuberante, e defende que o espetáculo tornou-se o modus operandi e vivendi social. A sociedade contemporânea é pautada pelo espetáculo, visto que o viver 'real' de cada participante é pobre e padronizante, o que faz com que os indivíduos consumam passivamente uma realidade espetacular para suprir o vazio de suas vidas. Essa reflexão ainda é atual. Podemos entender que qualquer esforço comunicacional realizado nos aparatos eletrônicos em rede estão sendo apropriados pela publicidade, seja com o objetivo de obter lucro ou fama, como ocorreu, por exemplo, no comercial viral da Coca-Cola (2015) em que um indivíduo começa a gargalhar no metrô/trem e contagia todos do vagão, fazendo-os rir juntos sem motivo algum, e no caso do youtuber Whindersson Nunes, que possui um canal com 42 milhões de inscritos, tendo 3,8 bilhões de visualizações. Youtubers como Whindersson Nunes (NUNES, 2021) são propagadores desses desafios que muitas vezes colocam os usuários das redes sociais digitais em risco (PORTELA; MARQUES, 2015).

Como citado anteriormente, o fenômeno do viral tem sido almejado por muitos usuários dos aparatos eletrônicos em rede, como também tem sido estudado pelo marketing. Além disso, a Ciência da Informação se dedica cada vez mais a entender o fluxo informacional do viral, questionando se o termo 'contágio' pode ou não, objetivamente, ser aplicado ao fenômeno. O estudo sobre o fluxo informacional de memes parece responder a tal problema: autores analisaram a disseminação de memes por meio da rede social Twitter em diferentes países e como os memes disputam a atenção humana. Apesar de o fenômeno parecer incontrolável, há um senão: o conteúdo viral tende à rápida entropia. Porém, o processo de disseminação do conteúdo tem um modo operacional que age de forma epidêmica e infecciosa, semelhante aos vírus biológicos (WENG; FLAMMINI; VESPIGNANI; MENCZER, 2012). Além disso, os autores afirmam que o contágio ocorre de maneira ininterrupta, ou seja, um conteúdo se sucede ao outro quase que infinitamente: “[...] embora os modelos epidemiológicos 
recentes tenham começado a considerar a disseminação simultânea [...], nossa estrutura é a primeira tentativa de lidar com um número praticamente ilimitado de novas 'epidemias' que são continuamente injetadas no sistema” (WENG; FLAMMINI; VESPIGNANI; MENCZER, 2012, p. o6, tradução nossa).

Entendendo que os termos não são meros batismos do marketing, ou seja, que há neles uma forma de comunicação diferenciada da de Lasswell (RÜDIGER, 2013), por exemplo, podemos perceber a relevância dos dados que as pesquisas supracitadas apresentam na compreensão do fenômeno.

\section{DESAFIOS DA INTERNET E O PAPEL DOS INFLUENCIADORES DIGITAIS}

Um dos pioneiros do epifenômeno aqui estudado foi o 'desafio do balde de gelo', em inglês 'ice bucket challenge', criado com o intuito de prospectar investimentos para pesquisas em prol da cura da doença Esclerose Lateral Amiotrófica (ELA). Iniciado nos Estados Unidos em agosto de 2014, o desafio consiste em filmar um indivíduo sendo banhado por um balde com água gelada e gelo e divulgar meios de realizar as doações. O desafio foi disseminado nas redes sociais, principalmente no Facebook e no YouTube, e cerca de 17 milhões de indivíduos postaram seus vídeos nas redes sociais, sendo assistidos 440 milhões de vezes (UM ANO..., 2015). A ALS Association, organização responsável por arrecadar os investimentos, revelou que nas primeiras duas semanas de agosto foram arrecadados 53 milhões de dólares. No ano anterior, 2013, a associação arrecadara 1,7 milhão de dólares utilizando-se de outras estratégias de comunicação (CARRERA, 2014). Celebridades como Donald Trump, Bill Gates, Mark Zuckerberg, Dave Grohl, Gisele Bündchen, Ana Maria Braga, Rafinha Bastos, entre outras, aceitaram o desafio e tomaram o banho de água gelada e gelo.

Ainda se discute se a aderência das celebridades foi positiva para disseminar o desafio e a campanha, visto que houve uma potencialização da arrecadação; contudo, aconteceram casos de autopromoção sem que se defendesse o que estava, de fato, em questão - o que já sinalizava que essas práticas seriam utilizadas para outros fins. No entanto, naquele momento ainda não era possível imaginar os extremos a que esses desafios chegariam (BITTENCOURT; GONZATTI; HENN; VIERO, 2015). A ferramenta Google Trends auxilia na investigação dessa efervescência do desafio; ao fazermos uma busca pelos assuntos 'Esclerose Lateral Amiotrófica' e 'desafio do balde de gelo', em todo mundo, no período de 2004 até 2020, em toda web, temos (Figuras 1 e 2):

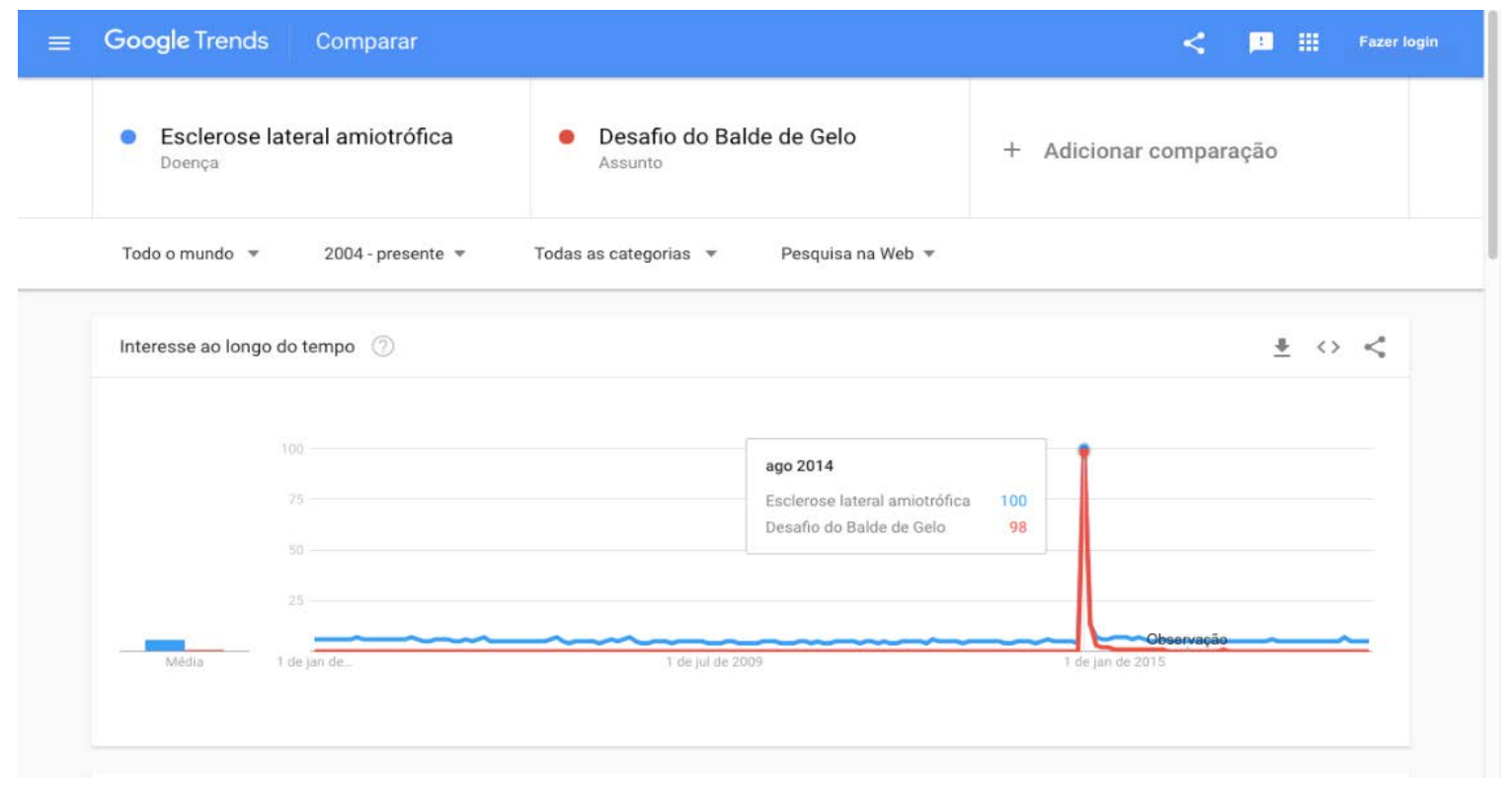

Figura 1 - Google Trends 'desafio do balde de gelo' 
Fonte: elaboração dos autores.

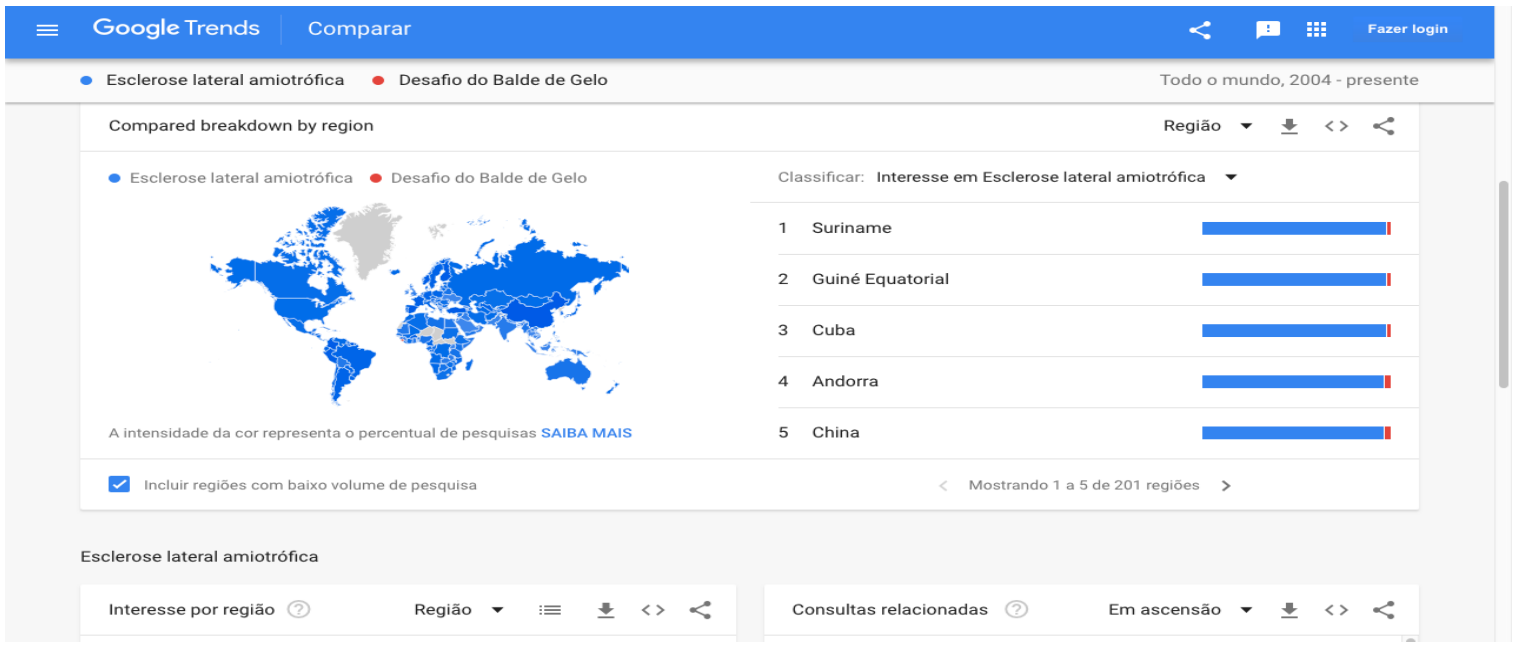

Figura 2 - Google Trends / Localidades 'desafio do balde de gelo' Fonte: elaboração dos autores.

Os índices de acesso apresentados pelo Google Trends revelam que no período em que o ‘desafio do balde de gelo' estava sendo disseminado nas redes sociais digitais, houve uma relevância tanto do desafio como da doença, obtendo o primeiro uma relevância de 98 pontos e o segundo, 100, em agosto de 2014. Os gráficos também demonstram que houve um contágio, iniciado com pouca relevância, maturando subitamente e cessando no mês seguinte. A ferramenta ainda revela que o contágio ocorreu em 201 regiões do mundo.

Antes de refletirmos mais sobre esse tipo de contágio, apresenta-se mais um caso, este conhecido como 'duct tape challenge' - no Brasil, como 'desafio da fita adesiva'. Consiste em se amarrar ou ser amarrado por um terceiro com uma fita adesiva e depois tentar escapar o mais rápido possível. O vídeo mais relevante na versão brasileira é do youtuber Felipe Neto, que atingiu cerca de 10 milhões de visualizações (NETO, 2017).

Apesar de parecer uma brincadeira inofensiva, um adolescente americano, Skylar Fish, sofreu um aneurisma cerebral. Fish fez o desafio na escola e dois amigos o gravaram enquanto amarravam seus braços e pernas. $\mathrm{O}$ adolescente estava em pé, mas, ao tentar se libertar, tropeçou e bateu com a cabeça no concreto, ferindo-se gravemente. Fish foi submetido a uma cirurgia de emergência e levou 48 pontos na cabeça (CABA, 2016).

No Google Trends foi pesquisada especificamente a relevância proveniente do YouTube, de 2008 até hoje, dos tópicos 'desafio da fita adesiva' e 'duct tape challenge'. O ápice acontece em janeiro de 2016, ganhando em um mês 100 pontos de relevância pelo mundo. Entretanto, em abril de 2015 e abril de 2017, existem ganhos consideráveis de cerca de 25 pontos de relevância. O desafio em questão atingiu cinco regiões do mundo, sendo o Brasil o país de maior relevância. Sabendo-se que houve um pico de 100 pontos de relevância, pode-se considerar este um caso de contágio. 


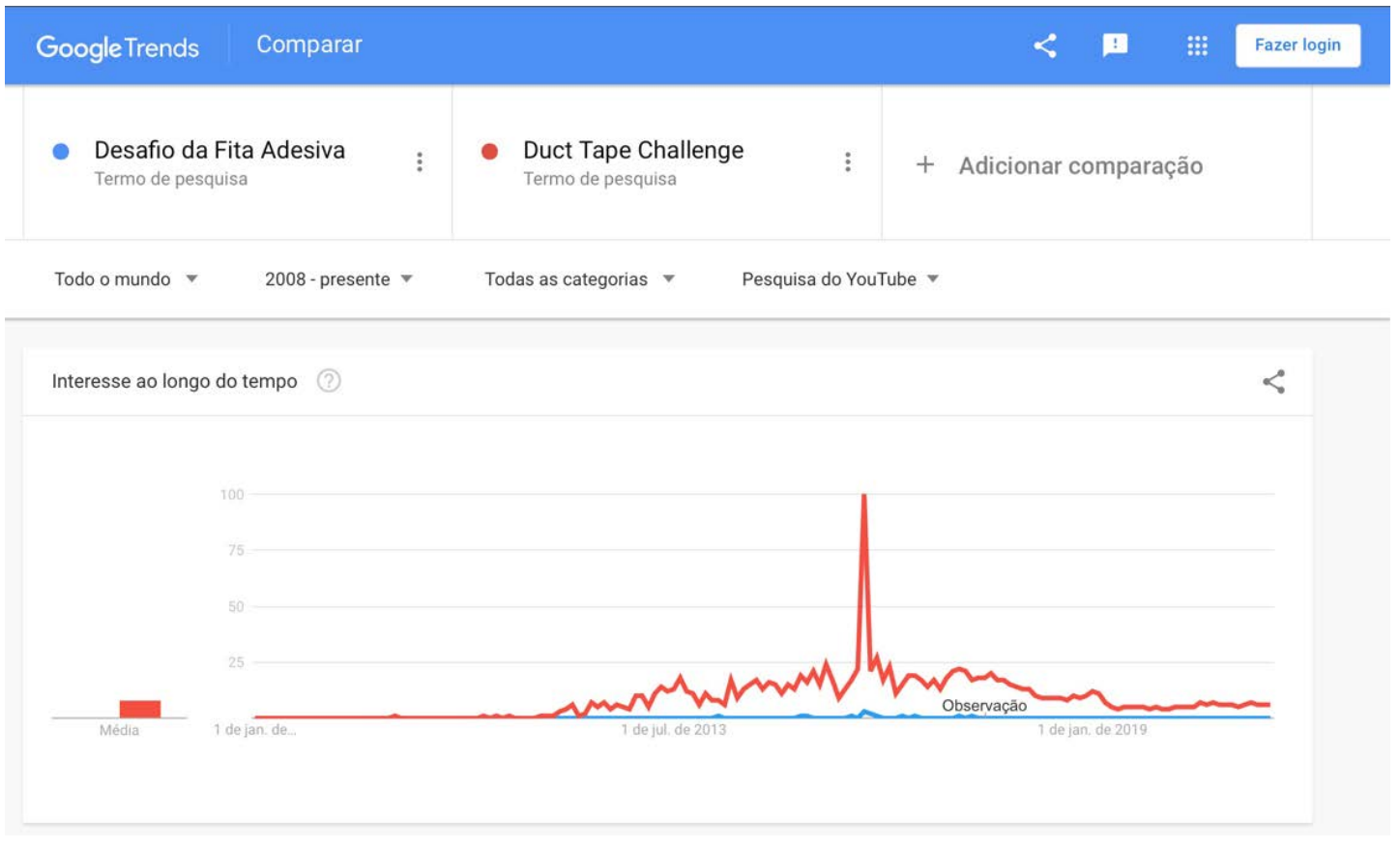

Figura 3 - Google Trends 'desafio da fita adesiva'

Fonte: elaboração dos autores.

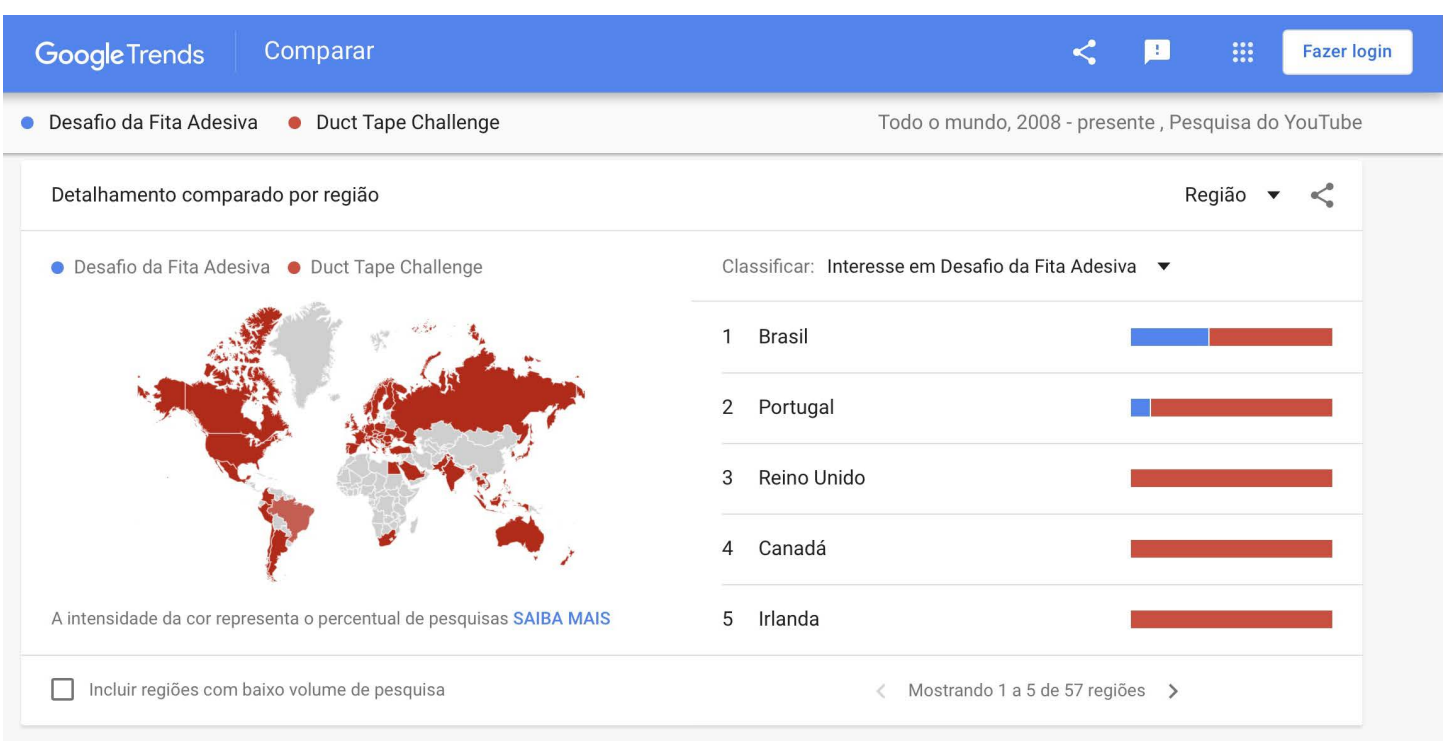

Figura 4 - Google Trends / Localidades 'desafio da fita adesiva' Fonte: elaboração dos autores.

Muito já se falou sobre o papel das celebridades e da influência delas nos padrões comportamentais e de consumo, mas quando falamos da faixa etária em questão, ou seja, pré-adolescentes e adolescentes, isso se torna mais grave, por ser esse um período de indefinições e de transição, no qual os conflitos acerca da identidade estão aflorados e se é capaz de gestos extremos em busca de aceitação e visibilidade.

O papel dos influenciadores digitais, bem como dos processos de contágio das massas, que já são próprios do ambiente mediático, amplificam-se nas novas gerações, que já nasceram mergulhadas nos ambientes digitais, compreendendo-os, em grande parte das vezes, como principal universo referencial de sociabilidade. Os atuais youtubers e influenciadores digitais parecem não estar ainda completamente conscientes dos impactos e das consequências de suas postagens, para além dos números de mercado. 


\section{O 'DESAFIO DE ASFIXIA' E O CONTÁGIO PSÍQUICO DAS MASSAS}

Segundo o Centro de Controle e Prevenção de Doenças (CDC) norte-americano, o 'jogo de asfixia', ou 'choking game', é um ato de autoestrangulamento ou de estrangulamento feito por outra pessoa (CDC, 2008, tradução nossa). Normalmente, as mãos ou um cinto são utilizados para estrangular o indivíduo, causando hipóxia cerebral - uma diminuição de oxigênio no cérebro, o que promove um estado de êxtase e alucinações:

[...] estas atividades de asfixia são praticadas com o objetivo de vivenciar sensações eufóricas e fugazes derivadas da hipóxia (diminuição da concentração de oxigênio no sangue), tais como alucinações visuais e/ou auditivas, sinestesias corpóreas (sensação de flutuar, de cair), sendo um 'sismo sensorial' por causa dos efeitos decorrentes da perda de consciência provocada pelo desmaio (GUILLHERI; ANDRONIKOF; YAZIGI, 2017).

Tal desafio foi muito popular no YouTube. Em 2016, foram registrados 419 vídeos de 'choking game', alguns de prevenção, porém a maioria ensinando técnicas para realizar o estrangulamento. Os vídeos foram produzidos de forma amadora por adolescentes, mas não apenas, como veremos a seguir. Nos vídeos, os jovens não só explicam como realizar o desafio, como também o descrevem como uma atividade de recreação. Em cerca de 80\% dos vídeos, incluindo os preventivos, havia cenas de adolescentes participando do desafio (CDC, 2008). Ocorre que isso pode incentivar outros adolescentes a praticarem o desafio, ao invés de preveni-lo. Em números, Guillheri, Andronikof e Yazigi (2017) ainda apontam que os vídeos de 'choking game' foram assistidos 22 milhões de vezes nas redes sociais, números que cresceram vertiginosamente.

Tal desafio cresceu tanto que foi necessário disseminar um alerta de prevenção, pois existem vários casos de morte por asfixia. O CDC (2008) aponta que o desafio é muito recorrente entre jovens de 6 a 19 anos - e 82 casos de óbitos teriam sido provavelmente causados pelo desafio de 1995 a 2007. A fim de atualizar o impacto desse fenômeno, outra pesquisa, feita em 2008, promoveu a aplicação de questionários em 687 escolas públicas nos Estados Unidos. Cerca de 10.642 alunos e pais foram entrevistados. O objetivo do questionário era conscientizar os pais e alunos da $8^{\mathrm{a}}$ série sobre o 'choking game'. O resultado foi que: $36,2 \%$ dos alunos entrevistados tinham ouvido falar do desafio; 30,4\% conheciam alguém que praticava o desafio; e 5,7\% tinham já tinham praticado ou ainda praticavam. E, ainda, cerca de $15,8 \%$ dos praticantes relataram que, junto ao desafio, eles utilizavam outras substâncias ilícitas.

Vide casos:

Caso 1. Em fevereiro de 2006, um adolescente de 13 anos chegou da escola de bom
humor e jantou com a família. Ele então foi para seu quarto para fazer sua lição de casa.
Aproximadamente uma hora depois, sua mãe foi ver como ele estava e o encontrou caído em
um canto com um cinto no pescoço. Seu rosto estava azul. A mãe começou a ressuscitação
cardiopulmonar, enquanto uma das outras crianças chamou uma ambulância. O menino
morreu em um hospital local uma hora depois. Nenhuma nota de suicídio foi encontrada.
O médico legista do condado determinou que a morte resultou de asfixia acidental por
enforcamento. Nas semanas seguintes à sua morte, vários adolescentes disseram ao
diretor de uma agência de aconselhamento local que o jogo de asfixia havia sido jogado
em festas locais. Caso 2. Em abril de 2005, uma adolescente de 13 anos foi encontrada
morta, pendurada em um cinto e cadarço feito em um laço na porta do armário de seu
quarto, depois que seu irmão foi ao seu quarto para ver por que ela não havia descido para
o café da manhã. Nenhuma nota de suicídio foi encontrada. O médico-legista determinou
que a adolescente tinha morrido às 9:30 da noite anterior. Após a morte da adolescente,
a família soube que a garota havia confidenciado a um primo que ela recentemente jogara
o jogo no vestiário da escola e que um grupo de garotas da escola havia sido suspenso por
jogar o jogo de asfixia (CDC, 2008, tradução nossa).

Os desafios ocorreram em 31 estados norte-americanos; não existe qualquer padrão geográfico. As práticas e as mortes não variaram por estação do ano ou por dia semanal. E não estão ligados a raça, etnia ou status 
social e/ou econômico. Além dos Estados Unidos, o desafio foi registrado em 10 países, em continentes diferentes, sendo 99 casos fatais (CDC, 2010).

No Google Trends, foi pesquisado sobre o 'jogo de asfixia', no tópico 'Assunto', estritamente na rede social YouTube. Vale a ressalva de que o resultado do Trends não equivale a indivíduos que publicaram suas práticas do desafio na rede social YouTube, mas equivale a indivíduos que se interessaram pelo desafio, ou seja, foram contagiados. O Google Trends revela que de janeiro a fevereiro de 2008 o desafio cresceu em relevância 75 pontos e no mês seguinte perdeu a relevância. Ao longo dos períodos ocorreram quatro crescimentos de 40 pontos, atingindo relevância em 89 regiões pelo mundo, configurando um processo de contágio.

\begin{tabular}{l|l|l|}
$\begin{array}{l}\text { Google Trends Pesquisar } \\
\text { Jogo de asfixia }\end{array}$ & + Comparar \\
\hline $\begin{array}{l}\text { Assunto } \\
\text { Todo o mundo } \quad \text { 2008- presente }\end{array}$ & Todas as categorias $-\quad$ Pesquisa do YouTube - \\
\hline
\end{tabular}

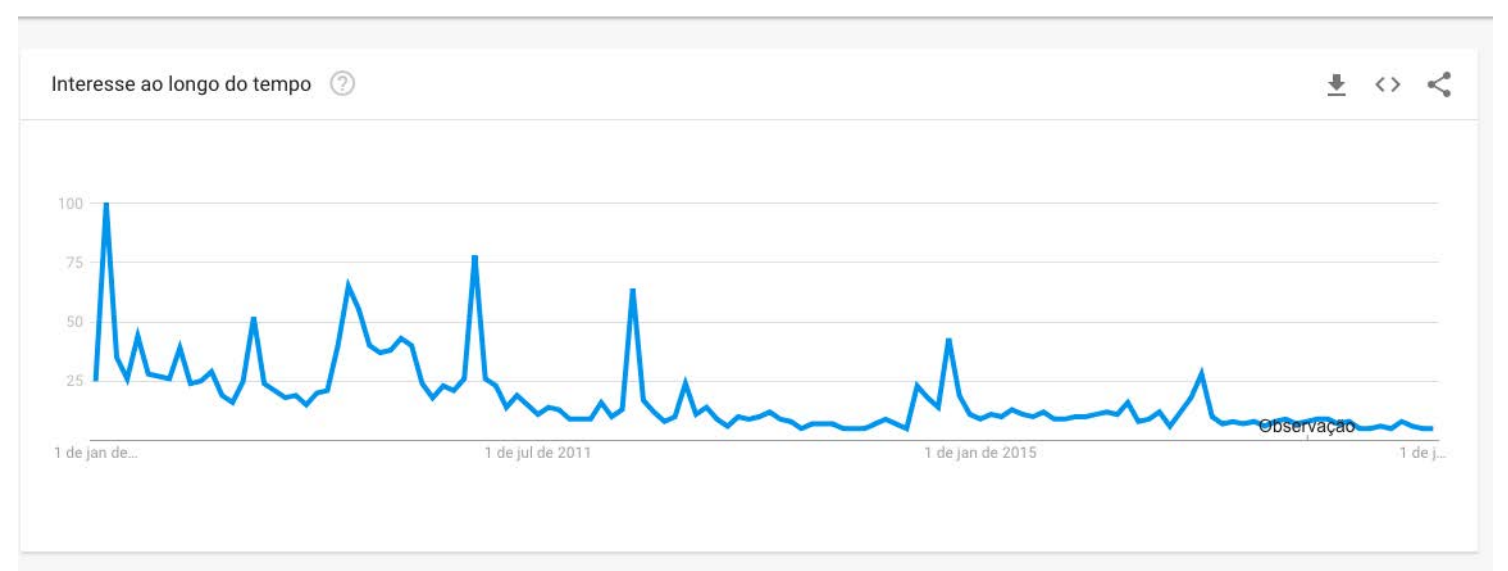

Figura 5 - Google Trends 'jogo de asfixia' Fonte: elaboração dos autores.

\begin{tabular}{|lll}
\hline Jogo de asfixia & Todo o mundo, 2008 - presente, Pesquisa do YouTube \\
\hline Interesse por região (2) & 1 Rússia & 2 Bielorrússia \\
\hline Incluir regiöes com baixo volume de pesquisa & 3 Cazaquistão & 4 Ucrânia \\
\hline
\end{tabular}

Figura 6 - Google Trends / Localidades 'jogo de asfixia' Fonte: elaboração dos autores.

A grande causa para jovens realizarem o desafio é uma necessidade de euforia, ou melhor, de atingir um estado alterado de consciência (ANDREW; FALLON, 2007). Por não haver ingestão de qualquer substância, crianças e adolescentes tendem a acreditar que a prática do desafio é segura. E ainda, "parece haver um subconjunto de jovens adolescentes com ansiedade e/ou depressão que, tendo um desejo de drogas e álcool 
para automedicação, mas limitado o acesso a esses agentes, recorre a esse tipo de comportamento como substituto" (ANDREW; FALLON, 2007, p. 305, tradução nossa).

Há relativamente pouco na literatura sobre comportamento asfixiante recreacional, com exceção de inúmeras variações sobre o tema da asfixia autoerótica (AEA), e ocasionalmente relatos de casos acidentais aparentes, no contexto do brincar, com crianças pequenas. Embora jogos de asfixia possam ser considerados por alguns uma forma de AEA, estes jogos não devem ser facilmente confundidos com AEA. O AEA é uma atividade semelhante, mas não relacionada, que envolve quase ligações ritualísticas, sofisticados mecanismos de escape, pornografia, cross-dressing, e está envolvida quase exclusivamente por adolescentes e adultos mais velhos do sexo masculino (ANDREW; FALLON, 2007, p. 305, tradução nossa).

Além da pesquisa que o Google Trends revelou, o 'choking game' foi considerado epidêmico (GUILLHERI; ANDRONIKOF; YAZIGI, 2017), indo ao encontro da hipótese do contágio proposto por este trabalho. Contudo, é necessário olhar para o fenômeno do 'choking game' considerando-o como sintoma. Afinal, se não for possível praticar o desafio, os participantes inventarão outras maneiras de se chegar ao êxtase, de se alucinar, de provocar experiências nas quais a adrenalina de ter a vida em risco conta mais que a sobrevivência. Há, portanto, um desafio que esses jovens estão lançando à sociedade - o de compreendermos o que está presente nesses 'desafios', nos quais supostas práticas de êxtase colocam a vida do praticante em sério risco.

\section{CONCLUSÃO}

A pesquisa aqui apresentada, por um lado, revela a existência de um processo que estamos designando como contágio das massas, vistos sua forma de irrupção, seus picos de adesão e seu rápido arrefecimento. Mais do que apenas uma analogia, o termo viral, utilizado para esses fenômenos, revela processos reais de contágio que, se obviamente não podem ser considerados biológicos, podem ser considerados contágios psíquicos das massas, claramente relativos a padrões de rede.

Evidenciou-se também a necessidade de refletir sobre as redes não apenas do ponto de vista tecnológico, mas sobretudo do ponto de vista dos sistemas vivos, a fim de realizar uma interação entre Psicologia e Comunicação nesse novo cenário das redes (CONTRERA, 2012). Se por um lado a tecnologia possibilitou identificar indícios de viralizações e depreender destas que ali existe um tipo de contágio das massas, por outro, é necessário ter atenção quanto às consequências da potencialidade dos contágios. Estes podem levar indivíduos a correrem risco de vida, como visto nos casos de 'choking game'.

O trabalho revela também uma preocupação no que tange à banalidade gerada pela sociedade mediática que tudo traduz em imagem técnica espetacular - é que "estamos além do panóptico, da visibilidade como fonte de poder e de controle. Não se trata mais de tornar as coisas visíveis a um olho externo, e sim de torná-las transparentes a si mesmas, pela perfusão do controle de massa, e apagando em seguida os traços da operação" (BAUDRILLARD, 2004, p. 22-23). A transparência, uma espécie de grau máximo de invisibilidade, é pensada como fruto da hipervisibilidade gerada, como saturação. Mas também podemos ver aí uma espécie de apagamento do corpo, uma negação radical da vida concreta, daquela que é, afinal, a única vida que nos é dada viver, a da carne, a da mortalidade tantas vezes negada e que volta, agora, como desejo - o desejo de morte mal disfarçado dos jovens que, em nome de uma diversão que busca o êxtase (mas que não conhece a imanência nem a transcendência), namoram intensamente com a própria morte (BAUDRILLARD, 2004).

Vale ainda ressaltar que não acreditamos que esses 'jogos' selecionados aqui sejam os únicos da internet - ainda surgirão outros. Porém, independentemente do método, há uma tendência 
contemporânea que contagia milhares de adolescentes e os faz simular e ensaiar a própria morte em jogos extáticos. Se por um lado a sociedade do espetáculo é vazia, por outro o fator humano almeja gozar a qualquer preço. Em síntese, é melhor gozar e continuar gozando pela possível morte literal, já que não existe mais um metarrelato, uma utopia que infle vida nos indivíduos (MELMAN, 2003).

Caso seja melhor brincar com a morte, se aproximar dela pelo jogo, talvez até acostumar-se com ela, ficar diante dela... a questão que se apresenta frente a esses fenômenos é sabermos se fecharemos os olhos para ver como Édipo, ou se continuaremos enfeitiçados pela luminosidade das telas até que tudo enfim transpareça/desapareça. É, no fim, um convite à morte, mas a humanidade deve decidir se essa morte será metafórica e promoverá transformações simbólicas (JUNG, 2013), ou se será literal, como já tem acontecido, quando se brinca com Tânatos ou mesmo quando se decide desafiá-lo com os virais da internet.

\section{REFERÊNCIAS}

ANDREW, Thomas A.; FALLON, Kim K. Asphyxial games in children and adolescents. The American Journal of Forensic Medicine and Pathology, [s. I.]. v. 28, n. 4, p. 303-307, dez. 2007. DOI: www.doi.org/10.1097/ PAF.0b013e318148bdb2. Disponível em: http://charlydmiller.com/LIB13/2007DecAsphyxialGames.pdf. Acesso em: 21 jul. 2020.

BAITELLO JUNIOR, Norval. A era da iconofagia: reflexões sobre imagem, comunicação, mídia e cultura. São Paulo: Paulus, 2014.

BAUDRILLARD, Jean. Telemorfose. Rio de Janeiro: Mauad, 2004.

BITTENCOURT, Maria Clara Aquino; GONZATTI, Christian; HENN, Ronaldo; VIERO, Felipe. O Desafio do Balde de Gelo como ciberacontecimento: celebridades como vetores-chave de espalhamento e apropriações.

Revista Fronteiras - estudos midiáticos, Rio de Janeiro, v. 17, n. 1, jan.-abr. p. 77-90, 2015. Disponível em: http://revistas.unisinos.br/index.php/fronteiras/article/view/fem.2015.171.08/4560. Acesso em: 12 jul. 2020.

CABA, Justin. Duct tape challenge gone wrong: teen almost died after attempting newest internet trend. MedicalDaily, [s. I.], 2016. Disponível em: https://www.medicaldaily.com/duct-tape-challenge-gone-wrong-teenalmost-died-after-attempting-newest-371138. Acesso em: 15 jul. 2020.

CARRERA, Isabela. O que o desafio do balde de gelo pode ensinar a outras campanhas online. Época, Rio de Janeiro, 23 ago. 2014. Ideias. Disponível em: https://epoca.globo.com/ideias/noticia/2014/08/o-que-obdesafio-do-balde-de-gelob-pode-ensinar-outras-campanhas-online.html. Acesso em: 12 jul. 2020.

CENTERS FOR DISEASE CONTROL AND PREVENTION (CDC). "Choking Game" Awareness and Participation Among 8th Graders - Oregon, 2008. Morbidity and Mortality Weekly Report, [s. I.], v. 59, n. 1, p. 1-5, 15 jan. 2010. Disponível em: https://www.cdc.gov/mmwr/pdf/wk/mm5901.pdf. Acesso em: 20 jul. 2020.

CENTERS FOR DISEASE CONTROL AND PREVENTION (CDC). Unintentional strangulation deaths from the "choking game" among youths aged 6-19 years - United States, 1995-2007. Morbidity and Mortality Weekly Report, [s. I.], v. 57, n. 6, p. 141-144, 15 fev. 2008. Disponível em: https://www.cdc.gov/mmwr/preview/ mmwrhtml/mm5706a1.htm. Acesso em: 19 jul. 2020.

COCA Cola - La felicidad comienza con una sonrisa. [S. I: s. n.], 2015. 1 vídeo (1:27 min). Publicado pelo canal 2mcgroup. Disponível em: https://www.youtube.com/watch?v=PytAkhHbcVY. Acesso em: 11 jul. 2020.

CONTRERA, Malena Segura. Emoção e imaginação: diferentes vínculos, diferentes imaginários. Ghrebh, São Paulo, n. 18, p. 188-201, out. 2012. Disponível em: http://www.cisc.org.br/portal/jdownloads/Ghrebh/ Ghrebh-\%2018/017_contrera.pdf. Acesso em: 21 jul. 2020.

CONTRERA, Malena Segura; TORRES, Leonardo de Souza Aloi. Imaginário e contágio psíquico. Intexto, Porto Alegre, n. 40, p. 11-22, set.-dez. 2017. Disponível em: http://seer.ufrgs.br/index.php/intexto/article/ view/73671/43474. Acesso em: 05 jul. 2020.

CONTRERA, Malena Segura; TORRES, Leonardo de Souza Aloi. Sob as asas de Tânatos: o que a obsessão pelo tema da morte revela. In: ENCONTRO ANUAL DA COMPÓS, 28., 11 a 14 de junho de 2019, 
Porto Alegre. Anais [...], [s. I.]: Compós, 2019. Disponível em: http://www.compos.org.br/biblioteca/trabalhos arquivo BYW4RJLIFVMEA3F5DTZ3_28 $7342 \_13 \_02 \_2019$ 12_43_30.pdf. Acesso em: 19 mai. 2021.

DEBORD, Guy. A sociedade do espetáculo. Trad. Estela dos Santos Abreu. Rio de Janeiro: Contraponto, 1997.

FREUD, Sigmund. Psicologia das massas e análise do Eu. Porto Alegre: L\&PM, 2017.

GOOGLE TRENDS. Explore what the world is searching. [S. I.]: Google, 2020. Disponivel em: https:// newsinitiative. withgoogle.com/training/lesson/4876819719258112?image=trends\&tool=Google\%20Trends. Acesso em: 06 jul. 2020.

GUILLHERI, Juliana; ANDRONIKOF, Anne; YAZIGI, Latife. "Brincadeira do desmaio": uma nova moda mortal entre crianças e adolescentes. Características psicofisiológicas, comportamentais e epidemiologia dos "jogos de asfixia'. Ciência e Saúde Coletiva, Rio de Janeiro, v. 22, n. 3, p. 867-878, mar. 2017. DOI: http://dx.doi. org/10.1590/1413-81232017223.14532016. Disponível em: https://www.scielo.br/scielo.php?script=sci arttext\&pid=S1413-81232017002300867\&lng=pt\&tlng=pt. Acesso em: 20 jul. 2020.

JUNG, Carl Gustav. Aspectos do drama contemporâneo. Petrópolis: Vozes, 2013.

LEBON, Gustave. Psychologie der massen. Stuttgart: Stuttgart Kröner, 1982.

LIMA, Paulo Niedersberg Correia; SAFFI, Fabiano Chiapinotto; FRANÇA, Ricardo Guimarães; WEBER, Raul Fernando. Vírus de computador. In: SALÃO DE INICIAÇÃO CIENTÍFICA, 8., 1996, Porto Alegre. Livro de resumos. Porto Alegre: UFRGS, 1996. Disponível em: https://lume.ufrgs.br/bitstream/ handle/10183/101459/000171245.pdf?sequence=1. Acesso em: 09 jul. 2020.

MELMAN, Charles. O homem sem gravidade: gozar a qualquer preço. Rio de Janeiro: Companhia de Freud, 2003

NETO, Felipe. DESAFIO: CANTA OU DUREX NA CARA! Com Raissa Chaddad [+13]. [S. I.; s. n.], 2017. 1 vídeo (12 min). Publicado pelo canal Felipe Neto. Disponível em: https://www.youtube.com/ watch?v=G8h5JUfg9uo\&t=486s. Acesso em: 15 jul. 2020.

NUNES, Whindersson. SOCIAL BLADE. [S. I.; s. n.], 2021. Disponível em: https://socialblade.com/youtube/ channel/UC3KQ5GWANYF8IChqjZpXsQw. Acesso em: 19 maio 2021.

PORTELA, Karoline Grubert Bezerra; MARQUES, Márcia Gomes. Produção cultural na internet: colaboração, consumo e interação comunicativa no Mato Grosso. In: CONGRESSO BRASILEIRO DE CIÊNCIAS DA COMUNICAÇÃO, 27., 4 a 7 de setembro de 2015, Rio de Janeiro. Anais [...], São Paulo, Intercom, 2015. Disponível em: https://portalintercom.org.br/anais/nacional2015/resumos/R10-0253-1.pdf. Acesso em: 19 maio 2021.

RIBEIRO, Matheus Araújo; ARAÚJO, Marcos Vinícius; NOGUEIRA, Mariana Guimarães; KELLER, Kátia Raquel Bonilha. As marcas na onda da viralização. In: CONGRESSO BRASILEIRO DE CIÊNCIAS DA COMUNICAÇÃO, 26., 4 a 7 de setembro de 2013, Manaus. Anais [...], São Paulo, Intercom, 2013. Disponível em: http://www.intercom.org.br/papers/nacionais/2013/resumos/R8-1491-1.pdf. Acesso em: 19 maio 2021.

RÜDIGER, Francisco. As teorias da cibercultura: perspectivas, questões e autores. Porto Alegre: Sulinas, 2013.

SILVA, Nelito Falcão da. Marketing viral: quando os internautas são a melhor propaganda. 2008. $164 \mathrm{f}$.

Dissertação (Mestrado em Comunicação) - Universidade de Brasília, Brasília, DF, 2008.

SOUZA, Ramon de. Os piores vírus da história da computação. Tecmundo, Curitiba, 28 jul. 2014. Malware. Disponível em: https://www.tecmundo.com.br/malware/59672-piores-virus-historia-da-computacao.htm. Acesso em: 10 jul. 2020.

TARDE, Gabriel de. Les Loi de l'imitation. Paris: Éditions du Seuil, 2001.

UM ANO após o desafio do balde gelo, o que aconteceu?. BBC News, São Paulo, 2 ago. 2015. Brasil. Disponível em: https://www.bbc.com/portuguese/noticias/2015/08/150802_desafio balde gelo um_ano lab Acesso em: 12 jul. 2020. 
Reciis - Revista Eletrônica de Comunicação, Informação \& Inovação em Saúde, Rio de Janeiro, v. 15, n. 2, p. 397-410, abr./jun. 2021 [www.reciis.icict.fiocruz.br] e-ISSN 1981-6278

VIERA, João. Jogos mortais na internet: como lidar com esse desafio? Proenem, [s. I.], 25 out. 2016].

Redação. Disponível em: https://www.proenem.com.br/enem/redacao/jogos-mortais-na-internet-como-lidarcom-esse-desafiol. Acesso em: 08 jul. 2020.

WENG, L.; FLAMMINI, A.; VESPIGNANI, A.; MENCZER, F. Competition among memes in a world with limited attention. Scientific Reports, Londres, v. 2, artigo 335, p. 1-8, 2012. Disponível em: https://www.nature.com/ articles/srep00335. Acesso em: 19 maio 2021. 